Jurnal Care Vol .5, No.3,Tahun 2017

\title{
KETERKAITAN AKTIVITAS FISIK DENGAN INDEKS MASSA TUBUH (IMT) SISWA SD KOTA MALANG
}

\author{
Nia Lukita Ariani ${ }^{1)}$ Swaidatul Masluhiya $\mathrm{AF}^{2)}$ \\ 1,2) Universitas Tribhuwana Tunggadewi, Jl. Telaga Warna, Tlogomas, Malang \\ e-mail: nia.ariani@rocketmail.com
}

\begin{abstract}
Obesity is one of the global health problems with increased morbidity and mortality rate. Obese children tend to be obese adult and this must be prevented. This study aimed to investigate the effect of nutritional intake and physical activity to body mass index at SD Sriwedari Malang and SDN Klojen Malang. The study design was an observational analytic research and used crosscetional approach. The samples were taken by using purposive sampling with a total of 76 students of $4^{\text {th }}-6^{\text {th }}$ class who were normoglicemic. The anthropometric measurement was done first then they were requested to recall $2 \times 24$ hours nutritional intake in two random days. The physical activity was measured by recalling their activity in holiday, weekday without exercise and weekday with exercise. The data were analyzed using Pearson Product Moment correlation test. Study's results showed most of students have higher physical activity than their nutritional intakes. There is no association between nutritional intakes with BMI while physical activity has great effect on BMI.
\end{abstract}

Keywords: physical activity, nutritional intakes, food recall, body mass index, children obesity

\begin{abstract}
ABSTRAK
Obesitas menjadi permasalahan kesehatan global dengan peningkatan rerata mobiditas dan mortalitas. Anak dengan obesitas cenderung menjadi dewasa obesitas dan hal ini harus dicegah. Penelitian ini bertujuan untuk mengetahui keterkaitan antara asupan gizi dan aktivitas fisik dengan Indeks Massa Tubuh (IMT) di SD Sriwedari Malang dan SDN Klojen Malang. Penelitian ini adalah penelitian analitik observasional dengan pendekatan cross sectional. Pengambilan sampel menggunakan total sampel sebanyak 76 siswa kelas 4-6 SD yang memiliki kadar glukosa normal. Pengukuran antropometri dilakukan pada tahap awal untuk kemudian siswa diminta mengingat kembali makanan yang dimakan selama 2x24 jam dengan hari yang tidak berurutan. Aktivitas fisik diukur dengan mengingat kembali kegiatan yang siswa lakukan pada hari libur, hari biasa tanpa pelajaran olahraga dan hari biasa dengan pelajaran olahraga. Data dianalisis menggunakan analisis korelasi Pearson Product Moment. Hasil penelitian menunjukkan sebagian besar siswa memiliki aktivitas fisik lebih tinggi dibandingkan asupan energinya.Uji statistik menunjukkan tidak ada hubungan antara asupan gizi dengan IMT sedangkan ada hubungan cukup kuat antara aktivitas fisik dengan IMT.
\end{abstract}

Kata kunci: aktivitas fisik, asupan gizi, food recall, indeks massa tubuh, obesitas anak 


\section{PENDAHULUAN}

Prevalensi obesitas meningkat beberapa dekade terakhir, bukan hanya di negara maju, melainkan juga di negara berkembang yang mengalami transisi nutrisi (Ellulu et al., 2014; Popkin et al., 2012). Peningkatan prevalensi obesitas tidak hanya terjadi pada kelompok usia dewasa, melainkan hampir merata pada seluruh kelompok usia. Secara nasional masalah gemuk pada anak umur 5-12 tahun masih tinggi yaitu sebesar $18,8 \%$, terdiri dari gemuk (10,8\%) dan sangat gemuk (obesitas) sebesar 8,8\%. Prevalensi gemuk pada remaja umur 13-15 tahun di Indonesia sebesar 10,8\%, terdiri dari $8,3 \%$ gemuk dan 2,5\% sangat gemuk (obesitas). Provinsi Jawa Timur termasuk salah satu provinsi yang memiliki prevalensi gemuk dan sangat gemuk melebihi prevalensi nasional (Badan Penelitian dan Pengembangan Kesehatan Kemenkes RI, 2013).

Obesitas merupakan kondisi tidak berimbangnya jumlah energi masuk yang berasal dari asupan gizi dengan energi yang digunakan baik untuk metabolisme basal maupun aktivitas lain. Adanya berbagai variasi makanan yang lebih gurih, lebih manis, lebih cepat dalam proses penyajiannya (fast food), dan ketersediaan edible oil menjadi penyebab peningkatan obesitas. Pola aktivitas fisik masyarakat juga cenderung bergeser menjadi sedentary lifestyle yang disebabkan oleh kemajuan teknologi (Popkin et al., 2012).

Obesitas pada anak selain disebabkan oleh faktor-faktor yang telah dijelaskan sebelumnya, Taylor et al. (2004) melaporkan faktor lain yang mungkin berpengaruh. Bayi yang memperoleh air susu ibu (ASI) di awal kelahiran hingga usia 6 bulan atau periode ASI eksklusif diketahui berisiko rendah mengalami obesitas pada masa kanak-kanak dibandingkan bayi yang memperoleh tambahan gizi selain ASI atau tidak mengkonsumsi ASI sama sekali selama periode tersebut. Selain itu, pengaruh media atau iklan berperan besar membentuk pola pikir anak tentang makanan enak yang identik dengan tinggi lemak dan kalori tetapi rendah serat (gizi kurang). Peran keluarga juga terlibat dalam pembentukan pola makan dan aktivitas fisik anak.

Permasalahan obesitas pada anak-anak mendapat perhatian lebih pada beberapa tahun terakhir. Anak-anak yang mengalami obesitas diketahui memiliki kecenderungan untuk menjadi remaja 
obesitas (Cunninghan et al., 2014) dan dewasa obesitas (Freedman et al., 2005). Risiko ini meningkatkan risiko anak-anak obesitas mengalami gangguan pernapasan, penyakit polycystic ovary, gangguan psikososial akibat diskriminasi dan tindakan bullying akibat obesitas serta beberapa penyakit metabolik, salah satunya diabetes mellitus (Oude et al., 2009). Deteksi dini status obesitas pada anak-anak merupakan suatu langkah preventif dalam mengatasi peningkatan prevalensi obesitas remaja dan dewasa. Pemahaman terkini tentang perubahan pola diet, peningkatan akses terhadap sumber makanan terutama makanan siap saji, dan keterbatasan alokasi waktu untuk akitivitas fisik dalam kegiatan harian anak menjadi informasi penting dalam mengetahui berbagai faktor determinan terjadinya obesitas. Data prevalensi obesitas pada anak terutama kelompok anak sekolah dasar (SD) yang kurang lengkap juga menyebabkan tindakan preventif dan kuratif obesitas pada anak belum maksimal.

\section{METODE PENELITIAN}

Penelitian ini merupakan studi analitik observasional dengan desain cross sectional. Penelitian dilakukan di SD Sriwedari Malang dan SDN Klojen Malang. Pemilihan sampel penelitian dengan teknik purposive sampling sesuai dengan kriteria inklusi meliputi siswa kelas 4, 5, dan 6 SD dan bersedia mengikuti penelitian dengan menyerahkan lembar informed consent yang diisi dan disetujui oleh orang tua/wali siswa. Siswa yang menderita asma karena aktivitas fisik, menderita sakit berat yang membutuhkan perawatan rumah sakit, mengkonsumsi obat-obatan yang mempengaruhi komposisi tubuh seperti pada sindrom cushing, diabetes mellitus, dan hipotiroid, mengkonsumsi obat secara regular, dan siswa berkebutuhan khusus (ABK) tidak diikutsertakan dalam penelitian ini. Sebanyak 76 siswa terlibat sebagai sampel penelitian. Penelitian ini telah disetujui oleh Komite Etik Penelitian Kesehatan Politeknik Kesehatan Kemenkes Malang.

Penentuan indeks massa tubuh (IMT) dilakukan dengan mengukur berat dan tinggi badan subyek tanpa menggunakan sepatu. Berat badan diukur dengan menggunakan timbangan injak yang berkapasitas $150 \mathrm{~kg}$ dengan ketelitian $0.1 \mathrm{~kg}$ (Laica). Sampel diukur pada posisi berdiri tegak tepat di tengah timbangan dan tanpa menggunakan alas kaki. Pembacaan angka dilakukan setelah angka penunjuk tidak bergerak. Data tinggi badan diukur dengan menggunakan alat 
ukur microtoise berskala $200 \mathrm{~cm}$ dengan ketelitian $0.1 \mathrm{~cm}$. Sampel diukur dalam posisi tegak, muka lurus ke depan dan tanpa menggunakan tutup kepala. Besi pengukur yang vertikal diturun naikkan hingga batang pengukur yang horizontal menyentuh tepat di atas kepala sampel. Posisi sampel membelakangi alat ukur dan pembacaan dilakukan dari salah satu sisi badan sampel. Pengukuran lingkar pinggang dan panggul menggunakan meteran jahit. Lingkar pinggang diukur di daerah sekitar pusar dengan mengambil area tersempit. Lingkar pinggul diukur di daerah pelvis dengan mengambil area terluas.

Data tentang asupan gizi meliputi jumlah energi, protein, lemak, dan karbohidrat yang dikonsumsi dalam sehari. diketahui dari food recall selama $2 \times 24$ jam dalam waktu yang acak atau tidak berurutan. Aktivitas fisik sehari- sehari yang dilakukan oleh siswa diidentifikasi melalui lembar deskripsi aktivitas fisik dengan 3 periode pengambilan data yaitu hari biasa tanpa pelajaran olahraga, hari biasa dengan pelajaran olahraga, dan hari libur. Analisis data untuk mengetahui pengaruh atau korelasi asupan gizi dan aktivitas fisik terhadap indeks massa tubuh (IMT) yaitu uji korelasi Pearson Product Moment.

\section{HASIL}

\section{Karakteristik Subyek Penelitian}

Subyek penelitian sebanyak 76 siswa dengan proporsi jumlah laki- laki dan perempuan yang hampir sama. Seluruh siswa merupakan siswa kelas 4- $6 \mathrm{SD}$, berusia antara 8-13 tahun saat penelitian berlangsung. Hasil pemeriksaan antropometri menunjukkan Indeks Massa Tubuh (IMT) yang sebagian besar dalam kategori normal dengan rasio lingkar pinggang dan panggul yang juga normal. Kadar gula darah sewaktu juga menunjukkan nilai rentang normal. sebagian besar siswa memiliki status gizi normal. Aktivitas fisik siswa secara keseluruhan lebih tinggi dibandingkan asupan energinya sehingga dapat menjadi faktor nilai IMT yang normal (Tabel 1).

\section{Pengaruh Asupan Gizi Terhadap Indeks Massa Tubuh (IMT) Siswa SD}

\section{Kota Malang}

Asupan gizi yang dikaji meliputi asupan energi total, protein, lemak, dan karbohidrat. Asupan energi total dan karbohidrat lebih rendah dibandingkan kebutuhan energi dan karbohidrat harian anak usia 10-12 tahun, sedangkan asupan protein dan lemak telah melebihi kebutuhan protein dan lemak harian anak usia 10-12 tahun. Hasil uji korelasi Pearson Product Moment menunjukkan tidak ada 
pengaruh asupan gizi baik dari asupan karbohidrat terhadap indeks massa tubuh energi total, lemak, protein, dan (Tabel 2)

Tabel 1. Karakteristik Umum Subyek Penelitian

\begin{tabular}{lr}
\hline \multicolumn{2}{c}{ Karakteristik Umum (n= 76) } \\
\hline Jenis Kelamin & $37(48,7 \%)$ \\
- Laki- laki, n (\%) & $39(51,3 \%)$ \\
- Perempuan, n (\%) & $10(8-13)$ \\
Usia (tahun) & $36 \pm 9,92$ \\
Berat badan (kg) & $1,38 \pm 0,08$ \\
Tinggi badan (m) & $18,58 \pm 3,63$ \\
Indeks Massa Tubuh $\left(\mathrm{kg} / \mathrm{m}^{2}\right)$ & $66(55-88)$ \\
Lingkar pinggang (cm) & $73,88 \pm 9,73$ \\
Lingkar panggul (cm) & $0,94(0,81-0,98)$ \\
Rasio Lingkar Pinggang dan Panggul & \\
(cm) & \\
Status Gizi & $4(5,3 \%)$ \\
- Kurus, n (\%) & $48(63,2 \%)$ \\
- Normal, n (\%) & $12(15,8 \%)$ \\
- Gemuk, n (\%) & $12(15,8 \%)$ \\
- Obesitas, n (\%) & $1431,5 \pm 48,67$ \\
Asupan Energi & $1888,8(890,93-$ \\
Aktivitas Fisik (keluaran energi) & $3183,19)$ \\
\hline
\end{tabular}

Tabel 2. Pengaruh Asupan Energi Terhadap Status Gizi Siswa SD Perkotaan Di Kecamatan Klojen Kota Malang

\begin{tabular}{lrr}
\hline Asupan Gizi- IMT & Mean \pm SD & p (0,05) \\
\hline Energi (kkal) & $1431,5 \pm 48,67$ & 0,647 \\
Protein (g) & $50,85 \pm 19,64$ & 0,448 \\
Lemak (g) & $74,87 \pm 39,56$ & 0,703 \\
Karbohidrat $(\mathrm{g})$ & $146,54 \pm 47,38$ & 0,581 \\
\hline
\end{tabular}

\section{Pengaruh Aktivitas Fisik Terhadap}

Indeks Massa Tubuh Siswa Siswa SD

\section{Kota Malang}

Hasil uji korelasi Pearson Porduct Moment menunjukkan bahwa ada pengaruh aktivitas fisik terhadap indeks massa tubuh $(p=0,000)$ dengan nilai 0,759 . Hal ini berarti aktivitas fisik berpengaruh cukup kuat terhadap indeks massa tubuh. Indeks massa tubuh pada anak - anak dapat digunakan sebagai parameter untuk menentukan status gizi.

\section{PEMBAHASAN}

Prevalensi obesitas pada anak usia 6-11 tahun mengalami peningkatan drastis 
dari 6.5\% pada tahun 1976- 1980 menjadi 18\% pada tahun 2009- 2010 (Fryar et al., 2012). Peningkatan ini disebabkan beberapa faktor antara lain faktor sosioekonomi dan demografi, lokasi tempat tinggal, gaya hidup dan asupan nutrisi (Rachmi et al., 2017). Penelitian ini diadakan di kawasan perkotaan dengan mempertimbangkan bahwa prevalensi obesitas lebih tinggi di kawasan perkotaan (Liu et al., 2012). Selain faktor lokasi perkotaan, prevalensi obesitas pada anak juga dimungkinkan lebih tinggi di sekolah swasta dibandingkan sekolah negeri disebabkan oleh faktor sosioekonomi yang mempengaruhi daya beli makanan dan asupan gizi (Kamelia et al., 2003). Data karakterisitik umum subyek penelitian menunjukkan bahwa parameter antropometri meliputi indeks massa tubuh (IMT), lingkar pinggal, lingkar panggul serta rasio lingkar pinggang dan panggul dalam rentang normal. Hal ini mungkin disebabkan oleh status ekonomi sebagian besar wali murid tergolong kelas ekonomi menengah ke bawah baik di sekolah umum maupun sekolah swasra (data tidak ditampilkan). Selain itu, aktivitas fisik subyek penelitian lebih tinggi dibanding asupan gizi yang dimakan.

Kebiasaan makan anak menjadi faktor risiko obesitas. Pola makan yang bergeser dari makanan siap saji yang kaya karbohidrat meningkatkan risiko obesitas (Japutra et al., 2015). Hasil penelitian ini menunjukkan tidak ada pengaruh asupan gizi total, karbohidrat, protein, maupun lemak terhadap IMT meskipun pola konsumsi siswa dalam penelitian ini cenderung mengkonsumsi jenis makanan fast food dan makanan berkalori tinggi lainnya yang sama seperti sosis, nugget, tempura, cilok, dan sedikit siswa yang mengkonsumsi sayur dan buah secara regular (data tidak disajikan).

Faktor risiko obesitas saling terkait antara satu faktor dan faktor lainnya. Sebagian besar siswa SD tergolong dalam IMT normal mungkin disebabkan karena aktivitas fisik siswa lebih tinggi dibandingkan asupan energi. Penelitian ini menunjukkan ada pengaruh aktivitas fisik terhadap IMT. Hasil ini sejalan dengan hasil penelitian sebelumnya oleh Gunter $e t$ al. (2015) yang menunjukkan bahwa ada korelasi antara aktivitas fisik yang dinyatakan dalam moderate vigorous physical activity (MVPA) dengan IMT yang lebih rendah pada anak sekolah dasar kelas 1-6.

Aktivitas fisik yang diidentifikasi dalam penelitian ini terbagi dalam tiga periode waktu yaitu aktivitas fisik pada hari 
sekolah biasa tanpa pelajaran olahraga, aktivitas fisik pada hari sekolah biasa dengan pelajaran olahraga dan aktivitas fisik pada hari libur (Primacakti et al., 2014). Tujuan penggunaan tiga waktu ini adalah untuk memperoleh gambaran lebih keseluruhan tentang aktivitas fisik siswa. Pada penelitian ini, diketahui sebagian besar siswa telah mengikuti full day school sehingga proporsi waktu beraktivitas dalam sekolah lebih lama. Selain itu, jenis aktivitas fisik yang dilakukan juga cenderung pada aktivitas fisik ringan dibandingkan aktivitas fisik moderat maupun berat.Hasil penelitian lain oleh Yu et al. (2002) menunjukkan bahwa anak dengan obesitas cenderung lebih kurang aktif dibanding anak dengan IMT normal. Hal ini juga terjadi pada dewasa dengan obesitas karena adanya perubahan metabolisme skeletal walaupun pada anak dengan obesitas, masih belum ditemukan penjelasan serupa (McManus \& Mellecker, 2012). Hasil yang berbeda dilaporkan oleh Cristoph et al. (2017) yang menunjukkan bahwa anak dengan IMT lebih tinggi justru ditemukan di lingkungan pedesaan dan dengan aktivitas fisik yang lebih tinggi.

Hasil penelitian tentang hubungan aktivitas fisik dan IMT yang bervariasi tetap tidak dapat menolak pemahaman umum tentang keuntungan fisiologis dari beraktivitas fisik (McManus \& Mellecker, 2012). Aktivitas fisik memberikan keuntungan bagi kesehatan tubuh. Aktivitas fisik khususnya olahraga dapat meningkatkan efisiensi miokardial melalui peningkatan aliran darah dan oksigen untuk memenuhi metabolisme local. Aktivitas fisik juga menurunkan risiko terjadinya resistensi insulin, intoleransi glukosa, hiperglikemia post prandial, dan gluconeogenesis hepatic. Aktivitas fisik diketahui memegang peranan terhadap distribusi lemak tubuh melalui penggunaan lemak dari daerah perut sebagai hasil redistribusi jaringan adiposa. Aktivitas fisik yang tidak adekuat menyebabkan semakin besarnya lemak tubuh yang ditimbun pada jaringan.

Ada beberapa keterbatasan yang mungkin perlu dipertimbangkan dalam menginterpretasi hasil penelitian ini. Pengukuran tentang aktivitas fisik dilakukan melalui metode self reporting sehingga memungkinkan adanya bias. Selain itu, IMT yang merupakan alat ukur termudah untuk menentukan status gizi belum bisa merepresentasikan secara keseluruhan perubahan pada komposisi lemak tubuh. Pemeriksaan langsung total energi yang dikeluarkan, dapat dipertimbangan untuk dilakukan di penelitian selanjutnya. 


\section{KESIMPULAN}

Aktivitas fisik siswa SD kota Malang lebih tinggi dibandingkan total asupan energi sehingga hal ini mungkin mempengaruhi indeks massa tubuh (IMT) siswa yang lebih banyak tergolong dalam kategori normal.

\section{UCAPAN TERIMA KASIH}

Penelitian ini didanai oleh Kemristekdikti dalam skim Penelitian Dosen Pemula tahun pembiayaan 2017. Penulis juga berterima kasih atas kerjasama SD Sriwedari dan SDN Klojen karena telah berpartisipasi aktif selama proses penelitian

\section{REFERENSI}

Badan Penelitian dan Pengembangan Kesehatan Kemenkes, RI. (2013). Riset Kesehatan Dasar. Jakarta.

Cristoph, MJ., Grigsby- Toussanit, DS., Baingana, R, Ntambi, JM. (2017). Physical Activity, Sleep, and BMI Percentile in Rural and Urban Ugandan Youth. Annals of Global Health, 83(2): 311-319.

Cunningham, SA., Kramer, MR., Narayan, KMV. (2014). Incidence of childhood obesity in the United States. N. Engl. J. Med. 370(5): 403411.
Ellulu, M., Abed, Y., Rahmat, A., Ranneh, Y., Ali, Faisal. (2014). Epidemiology of obesity in developing countries: challenges and prevention. $H O A J$ : 1-6.

Freedman, DS., Khan, LK., Serdula, MK., Dietz, WH., Srinivasan, SR., Berenson, GS. (2005). The relation of childhood BMI to adult adiposity: the Bogalusa heart study. Pediatrics. 115(1): 22-27.

Fryar, C.D., Carroll, M.D., Ogden, C.L.(2012). Prevalence of obesity among children and adolescents: United States, trends 1963-1965 through 20092010_obesity-2009-10 trends.pdf. http://www.nccpeds.com/Continu ityModules-

Fall/Fall $\% 20$ Continuity $\%$ 20Source $\% 20$ Materials/Obesity2009-10\%20Trends.pdf (Diakses pada 1 Oktober 2017)

Gunter, KB., Nader, PA., John, DH. (2015). Physical Activity Levels and Obesity Status of Oregon Rural Elementary School Children. Preventive Medicine Reports. 2: 478-482. Japutra, A., Fadlyana, E., Alam, A. (2015). Risk Factor for Obesity in 6-12 Years Old Children. Paedatrica Indonesiana, 55(1): 35-39. 
Kamelia, E., Nurdiani., Sembiring, T., Hakimi., Lubis, IZ. (2003). Obesity among children aged $10-13$ years in public and private elementary school. Paedatrica Indonesiana, 43(34): 38-41.

Liu LL., Lawrence JM., Davis C., et al. (2009). For the SEARCH for Diabetes in Youth Study Group. Prevalence of overweight and obesity in youth with diabetes in USA: the SEARCH for Diabetes in Youth Study. Pediatr Diabetes. 11(1): 4-11.

McManus, AM., Mellecker, RR. (2012). Physical Activity and Obese Children. J of Sport and Health Sci, 1: 141-148.

Oude, LH., Baur, L., Jansen, H., Shrewsbury, VA., O’Malley, C., Stolk, RP., et al. (2009). Interventions for treating obesity in children. Cochrane Database Syst Rev. (1).
Popkin, BM., Adair, LS., Ng, SH. (2011). Global Nutrition Transition and The Pandemic Obesity in Developing Countries. Nut Rev, 70(1): 3-21.

Primacakti, F., Syarif, DR., Advani, N. (2014). Physical Activity Assessment in Obese and Non Obese Adolescents Using Bouchard Diary. Paedatrica Indonesiana, 54(3): 137-143.

Rachmi, CN., Li, M., Baur, LA. (2017). Overweight and obesity in Indonesia: prevalence and risk factors- a literature review. Public Health, 147: 27-29.

Taylor, JH., Alexander, J., McBride, J. (2004). Overweight and Obesity in Children: A Review of the Literature. 146.

Yu, CW., Sung, RYT., So, R., Lam, K., Nelson, EAS., Li, AM, et al. (2002). Energy Expenditure and Physical Activity of Obese Children: Cross Sectional Study. Hong Kong Med J, 8: 313-317. 